Breeding, genetics, and reproduction

\title{
Correlation between urinary tract infection and reproductive performance of sows
}

\author{
Rafael de Moura1, Fabiana Ribeiro Caldara1 (D), Luciana Foppa ${ }^{2^{\star}}$ (iD), Simone Pereira Machado', \\ Irenilza de Alencar Nääs ${ }^{3}$ (ID, Rodrigo Garófallo Garcia ${ }^{1}$ (iD), Liliane Maria Piano Gonçalves ${ }^{1}$ \\ ${ }^{1}$ Universidade Federal da Grande Dourados, Faculdade de Ciências Agrárias, Dourados, MS, Brasil. \\ ${ }^{2}$ Universidade Estadual de Londrina, Centro de Ciências Agrárias, Londrina, PR, Brasil. \\ ${ }^{3}$ Universidade Estadual de Campinas, Departamento de Engenharia Agrícola, Campinas, SP, Brasil.
}

\begin{abstract}
This study aimed to assess the prevalence and influence of urinary tract infection on the reproductive performance of sows. The animals underwent urine tests using reagent strips and diagnosed as positive or negative. They were then divided into two groups of 30 positive and 30 negative sows for urinary tract infection. Each sow was considered an experimental unit and was followed from labor to weaning. The animals were assessed for their reproductive performance (labor duration, number of live births, mummified piglets, and stillbirths, and postpartum diseases). After weaning, the weaning-estrus interval and rate of return to estrus were assessed. A thermographic camera was used to identify hyperthermia of the mammary system and its relation with the onset of urinary tract infections. The prevalence of urinary tract infection in prepartum sows was 41.1\%. Urinary tract infection does not impact labor duration, number of live births, mummified piglets, and stillbirths, number of sows culled, weaning-estrus interval, or return to estrus after insemination. However, it was considered a predisposing factor for the occurrence of postpartum vaginal discharge. There is no correlation between the occurrence of urinary tract infection and mammary system temperature in sows.
\end{abstract}

Key Words: animal health, cystitis, mortality, pigs, reproduction

\section{Introduction}

Urinary tract infections (UTI) are highly prevalent in current pig production systems and cause economic losses due to the predisposition to reproductive failures and shortening of the useful life of sows, thus increasing the rate of sow culling.

Overall, its etiology is based on microorganisms of the fecal microbiota. Among those, the most common are Escherichia coli and Actinobaculum suis. Urinary tract infections may feature rotation or changes in etiological agents, i.e., one event may be caused by a given agent and a future infection, by another microorganism. The infection may also be caused by several agents simultaneously (Sobestiansky et al., 1999).

These infections usually evolve with no evident clinical signs and may go unnoticed, which causes the diagnosis to be often ignored. For diagnostic purposes, the prevalence

Received: March 26, 2018

Accepted: May 21, 2018

*Corresponding author: lufoppa@yahoo.com.br

Copyright $\odot 2018$ Sociedade Brasileira de Zootecnia. This is an Open Access article distributed under the terms of the Creative Commons Attribution License (http://creativecommons.org/licenses/by/4.0/), which permits unrestricted use, distribution, and reproduction in any medium, provided the original work is properly cited. of the disease in the herd must be known first. A significant urine sample must be collected for testing with a reagent strip, which is an auxiliary chemical text for indirect diagnosis. When strips are used, sows whose urine samples are positive for nitrite and/or blood are considered positive. The presence of nitrite in urine indicates colonization by bacteria able to reduce nitrate into nitrite. The $A$. suis bacterium is unable to perform this action. Hematuria is one of the major clinical signs of UTI caused by $A$. suis. Thus, the presence of blood in the reagent strip test indicates a probable infection by this agent. Prevalence above $15 \%$ indicates a severe, evolving problem, while prevalence above $25 \%$ indicates a very severe, chronic problem. After the prevalence is known, the next step is to carry out the bacteriological test and antibiogram of samples with positive results in the reagent strip test to verify the etiological agents and define the best course of therapy (Sobestiansky et al., 1999; Mazutti et al., 2013).

Collective treatment via feed is widely used since it is convenient and does not require individual diagnosis. However, this type of therapy has negative consequences to the herd, such as inespecificity of the antibiotic and drug underdosing. The fact that sows are treated simultaneously regardless of having or not UTI may lead to ineffective 
treatment and bacterial resistance against the antibiotics used (Jiang et al., 2011; Drummond and Perecmanis, 2013).

Urinary tract infections may be considered a predisposing factor for reproductive disorders such as smaller farrowings, lower milk production, poor performance of infant piglets, longer labor duration, dystocic labor, endometritis and mastitis, higher rates of return to estrus after insemination, and sow mortality (Amaral et al., 2000; Biksi et al., 2002; Mainau and Manteca, 2011; Oliviero et al., 2013).

Thus, this study aimed to assess the prevalence and influence of UTI on the reproductive performance of sows.

\section{Material and Methods}

The trial was carried out in a commercial farm in the city of São Gabriel do Oeste, MS, Brazil (19² 23' 42" S latitude and 54 $33^{\prime}$ 57" W longitude). The research complied with ethical standards and was approved by the Ethics Committee on Animal Use (permit 05/2015).

Initially, 73 sows in the prepartum period (approximately five days prior to labor) were assessed. All animals belonged to the same genetics and had the same dietary and management conditions.

Sows were housed in a masonry barn in individual suspended cages with individual access to automatic feeding troughs and bowl drinking troughs.

The exclusion criteria for the trial were animals having previous unsatisfactory reproductive performance and evident clinical alterations that could compromise the performance during lactation.

All sows were identified according to the parity before being transferred from the gestation sector to the maternity rooms. Urine was then collected and tested with reagent strips. The treatments comprised group I - sows positive for UTI; and group II - sows negative for UTI.

After the test results, 30 sows were selected for each group to have their reproductive performance assessed. Both groups were formed with sows of similar parity. Animals were then distributed in a completely randomized design with two treatments, and each sow was considered an experimental unit, characterizing one repetition.

Urine was collected between three and five days prior to labor in the morning before the first feeding. Appropriate urine collectors were used to store the samples. The first urine fractions were discarded, and only the final fraction of urine was collected. After collection, samples were identified with the number of the animal and underwent physical and chemical tests. The characteristics assessed followed methodologies employed by Alberton et al. (2000), Pôrto et al. (2003), and Menin et al. (2008):
Color: samples visually classified as colorless, light yellow, or dark yellow.

Odor: samples classified as having characteristic odor of the species or ammonia odor.

Turbidity/aspect: samples classified as clear, cloudy, or cloudy with lumps.

Chemical test: the chemical test was performed using specific reagent strips for urine analysis.

The reagent strip was fully immersed in the sample for five seconds, according to the manufacturer's instructions, making sure all squares were immersed. Soon after the strips were immersed in the urine, excess liquid was removed, and the tester waited the time indicated by the manufacturer for the chemical reaction before performing the reading by comparing the colors in the strip with those obtained in the samples.

Sows were considered positive for UTI if the reagent strip tests indicated presence of nitrite and/or blood in the samples, as described by Alberton et al. (2000), Pôrto et al. (2003), and Menin et al. (2008).

The animals housed in the farrowing room were clinically inspected daily from their arrival until weaning. The inspections assessed rectal temperature, appetite, presence of vaginal discharge, presence of mastitis and/or agalactia, and use of parenteral medication.

In addition, a thermographic camera was used to identify hyperthermia of the mammary system and assess its relation with the presence of UTI, besides evaluating the tool as a way of performing the early diagnostic of mammary problems. Thermographic images were acquired twice a day, at 9:00 and 15:00 h, during the five days after labor. A Hottec HT3 thermovisor with emissivity coefficient of 0.96 was used, and the software IR Reporter v. 1.0.146 was employed to convert the color spectrum into surface temperature to calculate mean temperatures of ten sites in the mammary system.

Labor duration was calculated from the average time adjusted for the number of piglets in the litter, since this number impacts labor duration. This adjustment was performed by dividing the actual labor duration by the number of piglets in the litter to obtain the interval of piglet birth. This interval was multiplied by the mean number of piglets per litter to yield the adjusted labor duration. The mean number considered was 12 piglets per farrowing. All times were written down in individual files for each sow.

The assessment of the reproductive performance of sows considered the following parameters: number of live births, stillbirths, and mummified piglets, adjusted labor duration, clinical signs of postpartum diseases (vaginal 
discharge, fever, loss of appetite, mastitis), number of culled sows, weaning-to-estrus interval, and return to estrus after insemination.

In the analyses regarding the reproductive performance of sows, data were compared by Mann-Whitney U-test. For subsequent reproductive performance analysis, the chisquared test was applied. In the assessments obtained from the thermographic images, the data underwent ShapiroWilk normality test, and the means were then compared by Student's t-test. All analyses were carried out in the software Assistat.

\section{Results}

The prevalence of UTI was $41.1 \%$, which is classified by Sobestiansky et al. (1999) as a very severe, chronic problem and likely evidences several risk factors such as inadequate facilities and management.

The physical assessments of urine showed that, in group I, of sows positive for UTI, $60 \%$ of samples had dark yellow color and $96.7 \%$ had ammonia odor. On the other hand, in group II, of sows negative for UTI, $80 \%$ of samples had characteristic odor of the species. In group I, $73.3 \%$ of samples were classified as cloudy and $20 \%$ as cloudy with lumps. In group II, $23.3 \%$ of samples were cloudy and $6.7 \%$ were cloudy with lumps. The physical evaluation showed that cloudy urine and with ammonia odor indicate the occurrence of UTI, as described by Alberton et al. (2000), Pôrto et al. (2003), and Menin et al. (2008). No significant difference was found between groups I and II regarding labor duration, which took on average $347 \mathrm{~min}$ (Table 1).

No difference $(\mathrm{P}>0.05)$ was found in reproductive performance (number of live births, stillbirths, and mummified piglets) of the sows in either group (Table 1). Different results were found by Amaral et al. (2000), who reported that UTI was considered a risk factor for the reduction in farrowing size. According to those authors, UTI led to a drop by 0.6 piglet per farrowing compared with sows with no UTI.

Table 1 - Reproductive performance in labor of sows positive and negative for urinary tract infection (UTI)

\begin{tabular}{lccc}
\hline Variable & $\begin{array}{c}\text { Group I } \\
(\mathrm{n}=30)\end{array}$ & $\begin{array}{c}\text { Group II } \\
(\mathrm{n}=30)\end{array}$ & Significance \\
\hline Average parity & 4 & 4 & - \\
Labor duration (min) & $389 \pm 86.22$ & $305 \pm 80.27$ & $\mathrm{NS}$ \\
Live births & $11.13 \pm 2.93$ & $12.30 \pm 2.12$ & $\mathrm{NS}$ \\
Stillbirths & $1.90 \pm 1.75$ & $1.73 \pm 1.25$ & $\mathrm{NS}$ \\
Mummified piglets & $0.2 \pm 0.34$ & $0.3 \pm 0.46$ & $\mathrm{NS}$ \\
\hline
\end{tabular}

Group I: sows positive for UTI; group II: sows negative for UTI. NS - non-significant.
Clinical inspection showed purulent vaginal discharge in $70 \%$ of sows in group I and in $16.7 \%$ of those in group II. The mean rectal temperature in the first five days after labor did not differ $(\mathrm{P}>0.05)$ between the groups, of 38.6 and $38.4{ }^{\circ} \mathrm{C}$ for groups I and II, respectively. No mastitis or agalactia was found in the clinical examination.

Removal of sows from the herd by culling or death was assessed and, by the end of the lactation period, $33.33 \%$ of the sows positive and $10 \%$ of negative for UTI were culled. Despite the high percentage, no significant differences were observed according to the chi-squared test. Urinary tract infection was not related to the number of sows culled from the herd.

After the breeders were culled due to reproductive disorders, 19 sows in group I and 24 in group II were selected for evaluation of rate of return to estrus after insemination. Four sows (one in group I and three in group II) were culled due to non-reproductive disorders and, therefore, they were not assessed regarding this parameter. Only one sow in either group returned to estrus $(5.3 \%$ for group I and $4.2 \%$ for group II); thus, no significant difference was found between the groups. The mean weaning-to-estrus interval did not significantly differ between the groups, 3.9 days for group I and 3.6 days for group II, which shows that UTI did not impact this parameter.

No differences $(\mathrm{P}>0.05)$ were found in the surface temperature of the mammary system assessed by infrared thermography. Therefore, in the present study, no correlation was found between the presence of UTI and disorders in the mammary system (Table 2). Sows assessed in the present study had no clinical mastitis; hence, no early diagnosis of the disease could be obtained through thermography images.

\section{Discussion}

When assessing physicochemical and microbiological aspects of the urine of culled sows, Pôrto et al. (2003) observed prevalence of UTI in $45.7 \%$ of urine samples. Through diagnosis using reagent strips, Alberton et al. (2000) identified high prevalence (28.3\%) for urinary tract diseases. Thus, the prevalence of UTI is high, and its occurrence can vary according to different risk factors on farms.

Table 2 - Mean surface temperature $\left({ }^{\circ} \mathrm{C}\right)$ of the mammary system of sows in lactation assessed by infrared thermography

\begin{tabular}{lccccc}
\hline Day & Day 1 & Day 2 & Day 3 & Day 4 & Day 5 \\
\hline Group I & 37.2 & 36.7 & 36.6 & 36.9 & 37.1 \\
Group II & 36.7 & 36.9 & 36.2 & 36.9 & 37.2 \\
Significance & NS & NS & NS & NS & NS \\
\hline
\end{tabular}

Group I: sows positive for urinary tract infection (UTI); group II: sows negative for UTI.

NS - non-significant. 
Borges et al. (2008) reported that the number of stillbirths significantly increases with labor duration in pigs. In the present study, $33.3 \%$ of sows in group II and $43.3 \%$ in group I had labor longer than $360 \mathrm{~min}$. Thus, UTI did not impact labor duration, and the complications in labor may have been caused by factors such as stress, temperature, and management.

Several other factors are related to reproductive performance of sows. Parity may impact the number of live births, and farrowings of first-parity sows are usually smaller than those of older sows (Bianchi et al. 2010). According to Mellagi et al. (2009), primiparous sows have longer labor and a higher number of stillbirths during manual obstetric intervention. Since the groups were formed based on sows being diagnosed with UTI and that a higher prevalence of the disease was found in the group whose parity was $<6$ $(50 \%)$, it was observed that older breeders are more prone to having UTI, as described by Sobestiansky et al. (1999).

Menin et al. (2008) reported that $93.98 \%$ of sows with clinical signs of some reproductive disorder were diagnosed as positive for UTI. Biksi et al. (2002) stated that animals with urocystitis are at 3.5 times higher risk of developing endometritis compared with those with no such infection.

Schaefer et al. (2004) reported an increase in temperature with the use of thermographic images in experimentally infected animals one week prior to the appearance of the first clinical signs. Martins et al. (2013) reported that sheep with subclinical mastitis had the highest udder temperature index; thus, thermography is an important tool to diagnose that group of animals. Similar results were found in cows by Polat et al. (2010) and Metzner et al. (2015), who concluded that subclinical mastitis and mastitis experimentally induced with $E$. coli, respectively, could be detected. However, reports in the literature concluded that the application of thermography must be properly assessed, and the characteristics of animals and environmental conditions must be taken into account, suggesting that further studies are required to prove its applicability as an early diagnosis method (Polat et al., 2010; Pérez de Diego et al., 2013; Martins et al., 2013; Amezcua et al., 2014; Menzel et al., 2015; Metzner et al., 2015; Soerensen and Pedersen, 2015).

\section{Conclusions}

Prevalence of urinary tract infection is high in sows in the prepartum period and may be a risk factor for the development of reproductive disorders. Labor duration, number of live births and stillbirths, number of culled animals, weaning-to-estrus interval, and rate of return to estrus are not impacted by the disease. Urinary tract infection is a predisposing factor to the occurrence of postpartum purulent vaginal discharge. However, there is no correlation between the occurrence of the disease and mammary system temperature in the sows.

\section{Acknowledgments}

The authors wish to thank Coordenação de Aperfeiçoamento de Pessoal de Nível Superior (CAPES), for the scholarship granted to the first author, and the Universidade Federal da Grande Dourados (UFGD), for the financial support.

\section{References}

Alberton, G. C.; Werner, P. R.; Sobestiansky. J.; Costa, O. D. and Barioni Júnior, W. 2000. Prevalência de infecção urinária e de Actinomyces suis em porcas gestantes e sua correlação com alguns parâmetros físicos e químicos da urina. Archives of Veterinary Science 5:81-88. https://doi.org/10.5380/avs.v5i1.3890

Amaral, A. L.; Morés, N.; Barioni Júnior, W.; Bortolozzo, F. P.; Sobestiansky, J. and Dalla Costa, O. A. 2000. Fatores de risco associados ao desempenho reprodutivo da fêmea suína. Arquivo Brasileiro de Medicina Veterinária e Zootecnia 52:479-486. https://doi.org/10.1590/S0102-09352000000500013

Amezcua, R.; Walsh, S.; Luimes, P. H. and Friendship, R. M. 2014. Infrared thermography to evaluate lameness in pregnant sows. Canadian Veterinary Journal 55:268-272.

Bianchi, I.; Lucia Junior, T.; Deschamps, D. C.; Scheinder, A.; Rabassa, V. R. and Corrêa, M. N. 2010. Indicadores de desempenho relacionado ao parto de fêmeas suínas de primeiro e segundo partos. Revista Brasileira de Zootecnia 39:1359-1362. https://doi. org/10.1590/S1516-35982010000600027

Biksi, I.; Takács, N.; Vetési, F.; Fodor, L.; Szenci, O. and Fenyo, E. 2002. Association between endometritis and urocystitis in culled sows. Acta Veterinaria Hungarica 50:413-423. https://doi. org/10.1556/AVet.50.2002.4.4

Borges, V. F.; Bernardi, M. L.; Bortolozzo, F. P. and Wentz, I. 2008. Perfil de natimortalidade de acordo com ordem de nascimento, peso e sexo dos leitões. Arquivo Brasileiro de Medicina Veterinária e Zootecnia 60:1234-1240. https://doi.org/10.1590/ S0102-09352008000500028

Drummond, V. O. and Perecmanis, S. 2013. Genes de enterotoxinas e perfil antimicrobiano de Escherichia coli isoladas de suínos hígidos no Distrito Federal. Arquivo Brasileiro de Medicina Veterinária e Zootecnia 65:1005-1009. https://doi.org/10.1590/ S0102-09352013000400010

Jiang, H. X.; Lü, D. H.; Chen, Z. L.; Wang, X. M.; Chen, J. R.; Liu, Y. H.; Liao, X. P.; Liu, J. H. and Zeng, Z. L. 2011. High prevalence and widespread distribution of multi-resistant Escherichia coli isolates in pigs and poultry in China. The Veterinary Journal 187:99-103. https://doi.org/10.1016/j.tvj1.2009.10.017

Mainau, E. and Manteca, X. 2011. Pain and discomfort caused by parturition in cows and sows. Applied Animal Behaviour Science 135:241-251. https://doi.org/10.1016/j.applanim.2011.10.020

Martins, R. F. S.; Paim, T. P.; Cardoso, C. A.; Dallago, B. S. L.; Melo, C. B.; Louvandini, H. and McManus, C. 2013. Mastitis detection in sheep by infrared thermography. Research in Veterinary Science 94:722-724. https://doi.org/10.1016/j.rvsc.2012.10.021 
Mazutti, K.; Locatelli-Dittrich, R.; Lunardon, I.; Kuchiishi, S. S.; Lara, A. C.; Zotti, E.; Montiani-Ferreira, F. and Alberton, G. C. 2013. Evaluation of the reagent test strips and microscopic examination of urine in the diagnosis of urinary tract infection in sows. Pesquisa Veterinária Brasileira 33:1103-1108. https://doi. org/10.1590/S0100-736X2013000900009

Mellagi, A. P. G.; Heim, G.; Bernardi, M. L.; Bortolozzo, F. P. and Wentz, I. 2009. Caracterização e desempenho reprodutivo de fêmeas suínas submetidas à intervenção obstétrica manual. Ciência Rural 39:1478-1484. https://doi.org/10.1590/S010384782009000500027

Menin, A.; Reck, C.; Capelli, J. C.; Ferraz, S. M. and Vaz, E. K. 2008. Diagnóstico de infecção urinária em fêmeas suínas produtivas em granjas comerciais no Sul do Brasil. Ciência Animal Brasileira 9:199-206.

Menzel, A.; Siewert, C.; Gasse, H.; Seifert, H.; Hoeltig, D. and Hennig Pauka, I. 2015. Infrared thermography of the pig thorax: a assessment of selected regions of interest by computed tomographical and anatomical parameters. Journal of Veterinary Medicine 44:107-117. https://doi.org/10.1111/ahe.12115

Metzner, M.; Sauter Loius, C.; Seemueller, A.; Petzl, W. and Zerbe, H. 2015. Infrared thermography of the udder after experimentally induced Escherichia coli mastitis in cows. The Veterinary Journal 204:360-362. https://doi.org/10.1016/j.tvj1.2015.04.013

Oliviero, C.; Kothe, S.; Heinonen, M.; Valros, A. and Peltoniemi, O. 2013. Prolonged duration of farrowing is associated with subsequent decreased fertility in sows. Theriogenology 79:10951099. https://doi.org/10.1016/j.theriogenology.2013.02.005
Pérez de Diego, A. C. P.; Sánchez Cordón, P. J.; Pedrera, M.; Martínez López, B.; Gómez Villamandos, J. C. and Sánchez Viscaíno, J. M. 2013. The use of infrared thermography as a non-invasive method for fever detection in sheep infected with bluetongue virus. The Veterinary Journal 198:182-186. https://doi.org/10.1016/j. tvj1.2013.07.013

Polat, B.; Colak, A.; Cengiz, M.; Yanmaz, L. E.; Oral, H.; Bastan, A.; Kaya, S. and Hayirli, A. 2010. Sensitivity and specificity of infrared thermography in detection of subclinical mastitis in dairy cows. Journal of Dairy Science 93:3525-3562. https://doi. org/10.3168/jds.2009-2807

Pôrto, R. N. G.; Sobestiansky, J.; Matos, M. P. C. and Gambarini, M. L. 2003. Aspectos físicos químicos e microbiológicos da urina de matrizes suínas descartadas. Ciência Rural 33:319-324. https://doi.org/10.1590/S0103-84782003000200021

Schaefer, A. L.; Cook, N.; Tessaro, A. V.; Deregt, D.; Desroches, G.; Dubeski, P. L.; Tong, A. K. W. and Godson, D. L. 2004. Early detection and prediction on infecting using infrared thermography. Canadian Journal of Animal Science 84:73-80. https://doi. org/10.4141/A02-104

Soerensen, D. D. and Pedersen, L. J. 2015. Infrared skin temperature measurements for monitoring health in pigs: A review. Acta Veterinaria Scandinavica 57:1-11. https://doi.org/10.1186/s13028015-0094-2

Sobestiansky, J.; Barcellos, D.; Mores, N.; Carvalho, L. F. and Oliveira, S. 1999. Clínica e patologia suína. 2a ed. Pfizer, Goiânia. 